University of Windsor

Scholarship at UWindsor

\title{
$5-2013$
}

\section{Characteristics of Immigrant Entrepreneurs and their Involvement in International New Ventures}

Francine K. Schlosser

Odette School of Business, University of Windsor

Roxanne Zolin

Follow this and additional works at: https://scholar.uwindsor.ca/odettepub

Part of the Business Commons

\section{Recommended Citation}

Schlosser, Francine K. and Zolin, Roxanne. (2013). Characteristics of Immigrant Entrepreneurs and their Involvement in International New Ventures. Thunderbird International Business Review, 55 (3), 271-284. https://scholar.uwindsor.ca/odettepub/125

This Article is brought to you for free and open access by the Odette School of Business at Scholarship at UWindsor. It has been accepted for inclusion in Odette School of Business Publications by an authorized administrator of Scholarship at UWindsor. For more information, please contact scholarship@uwindsor.ca. 


\title{
Post print: Characteristics of immigrant entrepreneurs and their involvement in international new ventures
}

Zolin, R.; Schlosser, F., Characteristics of Immigrant Entrepreneurs and their Involvement in International New Ventures, Thunderbird International Business Review, 55(3), 271-284, 2013, May.

\begin{abstract}
We studied 561 young firms in Australia to understand the involvement of immigrant entrepreneurs (IE) in international new ventures (INV). We found that IE are overrepresented in INV and have many characteristics known to facilitate INV success including more founders, university degree, international connections and technical capability. Our study has implications for immigration policy and economic policy and the efficient use of a nation's human capital. This research challenges a necessity-based stereotype of immigrant entrepreneurs by identifying areas in which immigrant entrepreneurs have natural competitive advantages over native entrepreneurs. This research makes a contribution to the theory of immigrant entrepreneurship by identifying the significant role of immigrant entrepreneurs in INV and the suitability of immigrant entrepreneurs for the development INV. We inform diverse streams of research in transnational and immigrant entrepreneurship with broader strategic work on the creation of INV.
\end{abstract}


Keywords: Immigrant Entrepreneur, international new ventures, transnational 


\section{Introduction}

Immigrant entrepreneurship 1) creates job opportunities for individuals who are overlooked by mainstream labour markets, 2) decreases competition with native-born workers, develops entrepreneurial role models, and 3) provides a way for immigrants to increase earnings (Zhou 2004). Through this lens, immigrant entrepreneurs (IE) are often characterised as experiencing barrier-based (push) self-employment (e.g. Zhou 2004). Barriers may be present in the destination (adopted) country's government policy (e.g. Tsui-Auch 2005) and in the labour market, including discrimination (Mata and Pendakur 1999; Mora and Davila 2005) and the unemployment level of the native-born (van Tubergen 2005), but a limited barrier-based perspective that profiles immigrant entrepreneurs as congregating in ethnic enclaves and primarily developing domestic new ventures (DNV) could reflect a myopic view from the perspective of the host nation, with little regard for immigrants' international human resources and potential. Indeed, previous research has indicated that the most appropriate success measures of barrierbased IE are limited to survival rather than based on growth and capitalization (Chrysostome 2010). From an opportunity-based view, immigrant entrepreneurs could have considerable human resources relevant to the development of international new ventures (INV), such as international knowledge, experiences and contacts, which would promote stronger success measures related to growth and revenues.

INV are businesses that, from inception, derive significant competitive advantage from the use of resources and the sale of outputs in multiple countries (Oviatt and McDougall 1994). As we seek to understand the nature of the global business economy 
with its diverse and mobile human capital, momentum is also growing to study how INV develop (e.g. Evangelista 2005). McDougall, Oviatt and Shrader (2003) found that international experience was one of the entrepreneurial characteristics linked to international sales in INV. In this new perspective, immigrant entrepreneurs operate on an international business playing field, employing their international human resources, such as education, connections and experience, to identify and exploit new international business opportunities.

There has been debate as to whether the changing economic role of immigrants is a new phenomenon or just newly discovered, and whether the trend toward understanding transnationalism is a natural evolution away from society's pre-occupation with assimilation (Portes, Guarnizo, and Haller 2002). For example, recently Ivan Light (2010, ix) described the evolution from a stereotype of immigrant business owners as owners of 'mom and pop stores' toward a better understanding of the economic importance of immigrant entrepreneurs, for example, as key players in the development of large international high tech ventures in Silicon Valley (Saxenian 2002).

We question the role of immigrant entrepreneurs in INV. We propose that compared to native entrepreneurs, immigrant entrepreneurs are over-represented in INV. We also propose that immigrant entrepreneurs will be over-represented in the human resources characteristics of INV, such as having more than one founder (i.e. a founding team), having a university degree, having international experience, having entrepreneurial experience, having industry experience, having international connections, and having technical capability. To investigate the role of immigrant entrepreneurs in INV, we use 
data from CAUSEE, a study of 1412 nascent, young and high profile firms in Australia, a country where $25 \%$ of its population are first generation immigrants.

\section{Literature Review}

\section{Developing International New Ventures}

International entrepreneurship reflects activities that cross national borders to create future goods and services (Honig and Drori 2010). Such organisations can become international at any stage in their life; for example, they may be 'Born Global' or begin domestically, and expand later to international markets. More specifically, International New Ventures (INV) are businesses that, from inception, target competitive advantage from the use of resources and the sale of outputs in multiple countries (Oviatt and McDougall 1994). An American field study of 214 new ventures conducted by McDougall, Oviatt and Shrader (2003) found that INV significantly differed on the basis of their entrepreneurial team experience, strategy, and industry structure. More specifically, McDougall, Oviatt and Shrader (2003) found that the founders of INV had high levels of international and industrial experience, their strategies had a high emphasis on innovation, differentiation and quality, included more marketing and distribution channels than DNVs, and they operated in more globally integrated industries. Evangelista (2005) provided qualitative insights into the venture creation process highlighting differences in founders, environment, processes and the organisation. Most notably, her interviews described characteristics of an INV founder including tendency toward working in teams, higher education, international experience, technical capabilities and previous industry and entrepreneurial experience. Her work provides a 
starting point for more generalisable quantitative study and the basis for our theoretical model (See Figure 1), which will be explained in the following literature review.

Previous 'Born Global' researchers have also identified factors that shape the development of INV (e.g. Oviatt and McDougall 1994; Knight and Cavusgil 1996; Madsen and Servais 1997) but have focused upon basic entrepreneurial firm behaviours and the uncertain international business environment with little study of ethnicity and multiple affiliations (Honig and Drori 2010, 201). Immigrant, Ethnic, and Transnational Entrepreneurship

Transnational entrepreneurship is a separate stream of international research, focusing on new ventures that stem from migration and globalisation. Transnational entrepreneurs migrate from one country to another but maintain linkages with both original and adopted countries in order to co-locate new business operations in both countries (Honig and Drori 2010). Portes, Guarnizo, and Haller (2002) noted that transnational entrepreneurs represent a large percentage (often the majority) of immigrants (to the United States) who are self-employed.

Originating in sociology and anthropology, the study of transnational and immigrant has been underexplored in the management literature (Chrysostome and Lin 2010). Much of the research is case based and limited in its generalizability. Indeed, this is a challenge for researchers to come to conclusions given the sometime contradictory results. For example, although founder education contributed to venture success for nonvisible ethnic minority immigrants, the opposite was found for visible ethnic minority immigrants (Kariv, Menzies and Brenner 2010). Previous research has highlighted that 
immigrant entrepreneurs of different ethnicities utilized personal and social capital quite differently in building their businesses. For example Brenner, Menzies, Dionne, and Filion (2010) found that the level of integration in the host country culture, and the desire to involve business contacts from country of origin differed across ethnic groups. Such differences increase the need for representative, cross-sectional studies when comparing IE to NE.

Researchers have also found differences in the characteristics and operations of IE and native entrepreneurs (NE). For example, IE were more likely than NE to develop strategic international relationships. (Hart and Acs 2011).

Model Development

These two research streams demonstrate the fragmentation in previous literature on international entrepreneurship, with the transnational stream emphasising ethnic and migration issues and the INV stream emphasising non-ethnic competitive issues. Our study attempts to connect these streams by examining the role of immigrant entrepreneurs in developing INV. In the following sections, we identify the phenomenon of immigrant entrepreneur founders in INV and consider how their unique human capital is conducive to forming INV.

Insert Figure 1 about here

\section{Immigrant Entrepreneur Involvement in INV}

Immigrants are nearly $30 \%$ more likely than natives to start a new business in the United States (Fairlie 2008). A potential difference among immigrant entrepreneurs lies in the ability to span multiple networks. Lechner, Dowling and Welpe (2006) explained firm 
networks and development as functions of the relational mix rather than of network size alone. Social networks are the largest network at the start of a firm's existence, and are most likely critical at the pre-foundation stage, when entrepreneurs are assembling their resources (Lechner, Dowling, and Welpe 2006). By utilising relevant foreign experience to bridge networks in different countries, immigrant entrepreneurs can take advantage of the price and value differentials between the two networks. Hence, some immigrants are more aware of international opportunities and better able to capitalise on them through international activities. Access to such varied networks provides greater opportunities to find pertinent resources than access to one large network (Granovetter 1985). This underlines a shift in thinking about immigrants and social capital. Instead of focusing on the disadvantages of a smaller network in their adopted country relative to native-born entrepreneurs, immigrants can build stronger competitive advantage on international experience through access to networks in adopted and original countries. In this new perspective, immigrant entrepreneurs operate on an international business playing field, employing their international human resources such as education, connections and experience to identify and exploit new international business opportunities. We propose that because immigrant entrepreneurs likely have the international knowledge, experiences and contacts that are linked to the development of INV (McDougall, Oviatt, and Shrader 2003), they will be over-represented in INV. However, over time, this competitive advantage that immigrants have relative to native entrepreneurs will diminish, as native entrepreneurs 'catch up' by building their own base of international knowledge, experiences and contacts. Hence: 
H1: A disproportionately high number of INV are founded by immigrants, compared to those founded by natives of the host country.

HIb: The percentage of international sales in firms started by immigrant entrepreneurs will be significantly higher than that of native entrepreneurs in the founding year but this difference will diminish over time.

\section{Founder Characteristics of INV}

Evanglista (2005) conducted a small in-depth interview study to understand what factors contributed to the emergence of INV. The data are based on in-depth interviews with the founders and focus on the major characters, events and context from the time the business idea was developed and through its evolution and entry into foreign markets (Evangelista 2005). From this qualitative study, Evangelista (2005) proposed that INV have more than one founder (i.e. a founding team), and that the founder is more likely to have a university degree, international experience, entrepreneurial experience, industry experience, international connections and technical capability. We suggest that in capitalising these characteristics, immigrant entrepreneurs are positioned to be 'pulled' into the creation of INV. In the next section we explore these propositions and develop further hypotheses.

\section{Capitalising Teams}

McDougall, Oviatt and Shrader (2003) concluded that founding teams with at least one member with international experience created a more successful INV. There are a 
number of practical and theoretical reasons why IE may be more likely than native entrepreneurs to form ventures using entrepreneurial teams. In some countries, new immigrants are subject to restrictions on enterprise ownership not experienced by native entrepreneurs. In order to expand their resources, IE may seek out partners to increase the equity in the firm, develop their business ideas, and to complement their international expertise. The establishment of a founding team could be seen as a way to smooth the development of their headquarters in the adoptive country. Brenner, Menzies, Dionne and Filion (2010) found that one of the greatest challenged faced by ethnic entrepreneurs is raising funds and they use their social capital in their ethnic networks to garner capital for their business through family and friends. Hence it would make sense to see more entrepreneurial teams in IE firms.

Additionally, immigrant accepting countries, such as the USA, Australia and Canada, tend to rate higher on scales of individualism than countries from which immigrants come, such as China, Vietnam and India (Hofstede, 1980). Hence we expect that immigrant entrepreneurs would be more likely than natives of these countries to gravitate towards entrepreneurial teams when starting a new business.

Pare, Menzies, Filion and Brenner (2008) investigated partnerships in five ethnic groups in Canada's three largest cities. They found a high incidence of partnerships, over $36 \%$, with Italians having the highest use of the co-leadership style (52\%), which involves a team of at least two people with complementary skills who work together and share managerial responsibility for finance, accounting, human resources, every day operations, marketing, sales, etc. 
Chaganti et al. (2008) concluded that new ventures with an ethnic-immigrant presence in the founding teams tended to pursue a more aggressive prospector strategy than those with non-ethnic, non-immigrant founding team members. However, the positive effects of ethnic-immigrant presence on founding teams depended on team size and average age of the founding team members. It could be that larger founding teams have more international contacts to employ in the INV. Hence, we propose that:

H2a: When compared to natives of the host country, immigrant entrepreneurs will be more likely to start a firm with a founding team.

H2b: When compared to natives of the host country, immigrant entrepreneurs will start a firm with a greater number of founders.

H2c: The higher the number of founders, the higher the percentage of international sales.

\section{Capitalising Education}

Previous researchers have connected higher education of the firm founder with firm growth (Ostgaard and Birley 1996). Immigrants are on average more highly educated than natives (Baker and Benjamin 1994) with more years of schooling (Ferrer and Riddell 2008), probably due to the country's immigration selection criteria. American research has also concluded that immigrants and immigrant children are likely to have higher educational aspirations than natives (Vernez and Abrahamse 1996). Students who pursue foreign studies may build upon their personal and social capital to become immigrant entrepreneurs (Schlosser and Kerr 2010). Such an individual process of learning and 
adaptation also helps to develop the cultural capital (Luo 2001) needed to transcend national boundaries. The opportunity to learn about more than one culture creates a unique advantage for immigrants and international students, and might stimulate the opportunities to develop ties needed to establish international ventures. Through their studies, international students have opportunities to meet other students, both international and from the host country. The exposure increases the size of the social networks and the likelihood that international students will be able to establish friendships. Previous research suggests that these friendships facilitate the formation of a management team, and they can support new venture performance (Francis and Sandberg 2000). Of special interest, international students are often well positioned while studying to develop a network of friends who are also from their home country, creating the strong potential for transnational partnerships (Neri and Ville 2008). Saxenian (2002) described the dominance of high-tech immigrant entrepreneurs in Silicon Valley, California. Wadwha et al. (2007) noted that $25 \%$ of the engineering and technology companies started in the late ' 90 s and early '00s were founded by immigrants. Accordingly, we hypothesize that:

H3a: Compared to native entrepreneurs, immigrant entrepreneurs are more likely to have a university education.

H3b: The higher the university education of the founder(s), the higher the percentage of international sales.

H4a: Compared to native entrepreneurs, immigrant entrepreneurs will have greater levels of technical capability than native entrepreneurs. 
H4b: The higher the technical capability of the founder(s), the higher the percentage of international sales.

\section{Capitalising Experience}

Immigrants arrive in their adopted countries with relatively high levels of international knowledge and experience. Previous research contrasting differences between INV and DNV in a U.S. survey of 214 new ventures found the entrepreneurial teams of INV exhibited higher levels of previous international experience (McDougall, Oviatt, and Shrader 2003). A recent Canadian study indicated that immigrant work experience in their countries of origin is valued much less than the experience of comparable natives (Ferrer and Riddell 2008). This lower return on educational investment in traditional employment might push immigrants to consider starting their own international venture. In this way they can better capitalise their foreign experience. Naturally, we expect that immigrant entrepreneurs will have greater international experience than native entrepreneurs. We propose that even within the select group of those starting INV, IE will have more international work experience than native entrepreneurs (NE). Hence, we propose:

H5a: Immigrant entrepreneurs engaged in INV will have higher levels of international work experience than NE engaged in INV.

H5b: The higher the international work experience of the founders, the higher the percentage of international sales. 
Individuals who start successful new ventures are likely to have had exposure to the industry, potentially 'learning the ropes' from mentors already owning a business (Georgellis, Sessions, and Tsitsianis 2005b). Evans and Leighton (1989) and Georgellis, Sessions and Tsitsianis (2005a) have all concluded that prior business ownership influences the decision to start a new venture. Researchers have found that successful entrepreneurs have a history of family business and utilise these family contacts in setting up their businesses (Greve and Salaff 2003), with their own business success correlated with prior work experience in a family business (Fairlie and Robb 2007). Notably, immigrants have developed these close family ties (Brenner and Toulouse 1990). Immigrants may find it easier to identify business opportunities in their adopted country that are associated with their prior industry and work experience accumulated in another country. Consequently, we propose IE will have greater entrepreneurial and industry experience:

H6a: Immigrant entrepreneurs will have higher levels of entrepreneurial experience than native entrepreneurs.

H6b: The higher the entrepreneurial experience of the founders, the higher the percentage of international sales.

H7a: Immigrant entrepreneurs will have higher levels of industry experience than native entrepreneurs.

H7b: The higher the industry experience of the founders, the higher the percentage of international sales. 
Among major industries, the highest representation of immigrant-owned business starts is in the wholesale and retail trade which capitalises their international connections (Fairlie 2008). While it is intuitive that IE will likely have more international connections than NE, IE may also value international connections more highly and seek to develop them. Hence, we propose:

H8a: Immigrant entrepreneurs will develop more international connections than native entrepreneurs.

H8b: The higher the international connections of the founders, the higher the percentage of international sales.

\section{Method}

To investigate the role of immigrant entrepreneurs in INV and DNV, we conducted a study of young firms in Australia, a country where $25 \%$ of its population are first generation immigrants. We drew data on 561 young firms from the Comprehensive Australian Study of Entrepreneurial Emergence (CAUSEE) project database (Davidsson, Steffens, Gordon and Reynolds, 2008), which provided a screened random sample of 1,186 Australian nascent and young business ventures. The data were collected during 2007/8 as part of a longitudinal panel study conducted over four years. Importantly for our study, this methodology allows for the random capture of active nascent and young ventures, thus gaining a more representative sample than most other survey methods. In the CAUSEE database, young firms with immigrant founders represented $26 \%$ of the sample, closely reflecting the percentage of immigrant entrepreneurs in the population. 
We created dichotomous variables to represent Immigrant entrepreneur, INV and most of the characteristics of INV. Immigrant entrepreneur is a dummy variable with 1 indicating the overseas born founder of the young firm, and 0 indicating a native born founder. International New Venture (INV) is coded with 1 indicating a new firm with international sales, while a 0 is a new domestic firm with no international sales. Additionally, we measured percentage of sales that were international as a continuous variable.

More than one founder (Team) was coded 1 if the founder answered the question 'Will the new business be owned only by yourself, only by yourself and your spouse/de facto, or by yourself and some other people or businesses?' with 'Self and spouse/de facto only' or 'Self and others'. Number of owners (Bus. Owners) was determined from the question: 'How many owners in total does the business have?'

University education was coded 1 if respondents reported a Bachelors or Higher University degree, e.g. Masters, Doctorate, as their highest level of education Depth of International experience (Intl Exp) was measured by years in other countries.

Breadth of international experience was measured by the number of countries worked in. International Depth was coded from the question: 'After the age of 18 but before starting this firm, how many years, if any, have you spend in countries other than Australia?' Breadth of International Experience was coded in answer to the question: 'After the age of 18 but before starting this firm, in how many countries outside Australia have you worked or studied for a period of three months or more?' 
Entrepreneurial experience was measured by the number of businesses currently owned.

Industry experience was measured by the answer to the question: 'Prior to starting this business, how many years of work experience, if any, did you have in the industry where this new business will compete?'

International Connections Face to Face (Intl ConF2F) was coded 1 when, asked to indicate which of the international activities their business is involved in, the respondent selected 'Exchange of ideas or information with individual colleagues abroad whom you meet in person, for example, at trade fairs?' International Connections Mediated by Technology (Intl Con Tech) was coded 1 when, asked to indicate which of the international activities their business is involved in, the respondent selected 'Exchange of ideas or information with individual colleagues abroad via phone, email or internet?'

Technical capability was assessed by R\&D, High-tech, and Proprietary technology (Prop tech). R\&D was coded 1 if respondents answered 'Yes' to the question: 'Is spending on research and development be a major priority for this business?' High technology was coded 1 if the respondents said they considered the business to be hi-tech. Proprietary technology was coded 1 if the respondent answered 'Yes' to the question 'Has this business developed any proprietary technology, processes or procedures that no other company can use, will it in the future, or is this not relevant to the new business?' 


\section{Analysis}

We used Logistic Regression Analysis to test the hypotheses with a dichotomous dependent variable, INV. The overall chi-square test was used to evaluate the null hypotheses that all coefficients in the model, except the constant, were zero, i.e. for the dependent variable there would be no difference between IE and not IE. If chi-square was significant, the probability of a greater chi-square with one degree of freedom (the difference in complexity between initial and final models), would be low enough to reject the null hypotheses. When the dependent variable was categorical we used Analysis of Variance (ANOVA) to test differences in means and Bartlett's test for equal variances.

\section{Results}

Table 1 shows the descriptive statistics for YF, Table 2 shows the correlations between all variables with significant relationships indicated. Table 3 shows the results of the logistic regression models with each dependent variable regressed on IE. Table 4 shows the results of the ANOVA for the categorical variables with the means of IE compared to NE. Table 5 shows the logistic regressions on INV in young firms.

Insert Tables 1, 2, 3, 4 and 5 about here

We expected that a disproportionately high number of international new ventures are founded by immigrants when compared to natives of the host country. Hypothesis 1 
was supported in YF since IE were more likely to have an INV than DE $(\mathrm{OR}=2.1$, $\mathrm{P}>\mathrm{Chi} 2=.001)$.

When compared to natives of the host country, Hypothesis 2a proposed that immigrant entrepreneurs will be more likely to start ventures with a founding team. This found only partial support in $\mathrm{YF}(\mathrm{OR}=.69, \mathrm{P}>\mathrm{chi} 2=.058)$. Hypothesis $2 \mathrm{~b}$ proposed that when compared to natives of the host country, immigrant entrepreneurs will start ventures with a greater number of founders. This was barely significant in $\mathrm{YF}(\mathrm{F}=2.72$, $\mathrm{P}>\mathrm{F}=.09)$.

Hypothesis 3 proposed that, compared to native entrepreneurs, immigrant entrepreneurs are more likely to have a university education. This was supported in YF $(\mathrm{OR}=1.71, \mathrm{P}>\mathrm{z}=.006)$.

We proposed in Hypothesis 4 that compared to native entrepreneurs, immigrant entrepreneurs will have greater levels of technical capability than native entrepreneurs. In YF, this was supported for $\mathrm{R} \& \mathrm{D}(\mathrm{OR}=1.61, \mathrm{P}>\mathrm{z}=.025)$, and High Technology $(\mathrm{OR}=$ $1.63, \mathrm{P}>\mathrm{z}=.02)$ and development of proprietary technology $(\mathrm{OR}=2.49, \mathrm{P}>\mathrm{z}=.002)$.

We proposed immigrant entrepreneurs will have higher levels of international experience than native entrepreneurs when starting INV. Hypothesis 5 was supported in YF for Depth of International Experience $(F=29.41, \mathrm{P}>\mathrm{F}=.000)$ but not for Breadth of International Experience in $\mathrm{YF}(\mathrm{F}=.19, \mathrm{P}>\mathrm{F}=.427)$.

In Hypothesis 6, we proposed that, compared to native entrepreneurs, immigrant entrepreneurs will have higher levels of entrepreneurial experience than native 
entrepreneurs. The difference in the average number of businesses currently owned was barely significant in $\mathrm{YF}(\mathrm{F}=2.74, \mathrm{P}>\mathrm{F}=.0982)$.

Compared to native entrepreneurs, immigrant entrepreneurs were proposed to have higher levels of industry experience than native entrepreneurs. Hypothesis 7 found only marginal support in $\mathrm{YF}(\mathrm{F}=3.68, \mathrm{P}>\mathrm{F}=.055)$.

Hypothesis 8 proposed that compared to native entrepreneurs, immigrant entrepreneurs will develop more international connections than native entrepreneurs. We found a significant difference in the means of IE compared to NE for International Connections Face to Face in $\mathrm{YF}(\mathrm{OR}=1.68, \mathrm{P}>\mathrm{z}=.015)$. We did not find a significant difference in International Connections Mediated by Technology for YF (OR $=1.18, \mathrm{P}$ $>\mathrm{z}=.570)$.

A number of hypotheses proposed positive relationships between the human resources characteristics and the starting of INV. The following relationships with INV are reported in Table 5: H2c: number of owners (Odds ratio $=0.98$, n.s.); H3b: university education (Odds ratio $=1.21, \mathrm{n} . \mathrm{s}$ ) $; \mathrm{H} 4 \mathrm{~b}$ : technical capability (R\&D: Odds ratio $=1.25$, n.s.; Hi tech: Odds ratio $=1.83, \mathrm{P}>\mathrm{z}=0.02$; Proprietary technology: Odds ratio $=1.63$, n.s.); H5b: international work experience (Depth: Odds ratio $=1.01$, n.s.; Breadth: Odds ratio $=1.15, \mathrm{P}>\mathrm{z}=0.04) ; \mathrm{H} 6 \mathrm{~b}$ : entrepreneurial experience (Number of businesses owned: Odds ratio $=1.14$, n.s.); H7b: industry experience (Odds ratio $=0.99$, n.s.); H8b: international connections $(\mathrm{F} 2 \mathrm{~F}$ : Odds ratio $=1.40$, n.s.; Through technology: Odds ratio $=$ $3.51, \mathrm{P}>\mathrm{z}=0.00)$.

A summary of our findings is displayed in Figure 2. 
Insert Figure 2 about here

SUMMARY OF RESULTS Immigrant entrepreneurs are often portrayed as being pushed into necessity-based entrepreneurship due to limited employment prospects. We questioned whether immigrant entrepreneurs may in fact use their international human capital to exploit international opportunities and develop INV. Our results indicate that a significantly higher percentage of immigrant entrepreneurs in our sample started INV than would be expected by their numbers in the population. IE were also over-represented in the possession of some of the characteristics associated with INV, including having a university education, depth of international experience, developing face-to-face international connections and greater technical capability. Other INV characteristics that were marginally significant included starting with a greater number of founders, entrepreneurial experience and industry experience. INV characteristics that were not significant were developing technology mediated international connections and number of businesses currently owned, which reflected entrepreneurial experience. These results flagged a clear pattern supporting the role of IE in INV.

Discussion

A significant percentage of IE leveraged their international human resources to develop INV. On average, IE are more likely to have the international human resources needed to start INV than native entrepreneurs but IE were not significantly more likely to start with an entrepreneurial team compared to NE or to have a greater number of founders. Thus our results are similar to Pare, Menzies, Filion and Brenner (2008), who 
found that some ethnic groups used partnerships more than natives, they could not conclude that ethnic entrepreneurs were more likely to form entrepreneurial teams. It may be that the tendency to form entrepreneurial teams is influenced by the specific ethnic group. More research is needed on this.

Similar to previous research (i.e., Baker and Benjamin 1984), we found that IE were more likely to have a university education than NE. These findings make sense in light of immigration policies in countries like Australia, the United States and Canada, where skills and education are required for the many categories of immigration visas. The establishment of an INV requires the development of international contacts but our results indicated that IE operating INV developed even more international connections than NE operating INV. This finding is aligned with research by Hart and Acs (2011), which concluded that immigrant-founded firms are more likely to report that they have a strategic relationship with a foreign firm.

We also found that IE operating INV have greater depths of international experience than NE operating INV, and although on average, IE had greater breadth of international experience compared to NE, but the difference was barely significant. This could be due to the great interest Australians young and old take in visiting overseas countries. Policy makers should keep in mind the potential future benefit to the economy of having a well-travelled population.

We expected to find that IE would also have greater entrepreneurial and industry experience. Although immigration policies favour immigrants with these skills, the bias 
towards higher skills in these areas may not be as great as for education. More research could determine the reason for no significant difference in this area.

It is interesting that IE are more likely to attend trade fairs and other face-to-face forms of meetings to develop international connections than NE, who seem to need the international connections more. Possibly being more familiar with the international business scene, they are even more aware of the need for such connections. Alternatively, IE may know of international events from prior international experience.

\section{Contributions}

This research makes a contribution to the theory of immigrant entrepreneurship by identifying the significant role of immigrant entrepreneurs in INV and the suitability of immigrant entrepreneurs for the development INV. We augment the immigrant entrepreneur literature (dominated by case-based method) and increase generalizability of findings through large-scale cross-sectional data collected from ethnic and immigrant entrepreneurs in Australia. We combine the literature and streams of research in transnational and immigrant entrepreneurship with that of the broader strategic work on the creation of INV. Our study has implications for immigration policy and economic policy and the efficient use of a nation's human capital. A common issue is the underutilisation of immigrants, who immigrate only to find that their skills and experience may not be transferable to the domestic market of their adopted country. This research challenges a necessity-based stereotype of immigrant entrepreneurs by identifying areas in which immigrant entrepreneurs have natural competitive advantages over native entrepreneurs. We examine how countries might optimally use their immigrant human capital. This study is 
limited by only being conducted in one country, Australia. Further research is needed to replicate this study in other countries and over time. Although comprehensive, the survey is single source administered at one point in time, and this may lead to some bias.

\section{Conclusion}

Immigrant entrepreneurs are often portrayed as being pushed into necessity-based entrepreneurship due to limited employment prospects. We questioned whether immigrant entrepreneurs may be more opportunity driven and in fact use their international human capital to exploit international opportunities to develop INV. Our results indicate that a significantly higher percentage of immigrant entrepreneurs start INV than would be expected by their numbers in the population. This can be explained by our findings that IE are also over-represented in possession of many of the characteristics associated with INV, such as having a university education, having greater depth of international work experience, making more face-to-face international connections and having greater technical capability. These results challenge the stereotype of a necessity driven IE. More research is needed to replicate this study in other high immigration countries, such as the USA and Canada. 


\section{References}

Baker, M., and Benjamin, D. (1994). The performance of immigrants in the Canadian labor market. Journal of Labor Economics, 12(3), 369.

Brenner, G., Menzies, T. V., Dionne, L and Filion, L. J. (2010). How location and ethnicity affect ethnic entrepreneurs in three Canadian cities, Thunderbird International Business Review. 52(2), 153-171

Brenner, G., \& Toulouse, J-M. (1990). Business creation among the Chinese immigrants in Montreal. Journal of Small Business and Entrepreneurship, 7(4),38-45.

Chrysostome, E. (2010). The success factors of necessity immigrant entrepreneur: in search of a model. Thunderbird International Business Review, Vol.52 (2), 137152.

Chrysostome, E. \& Lin, X. (2010). Immigrant Entrepreneurship: Scrutinizing a Promising Type of Business Venture. Thunderbird International Business Review, Vol. 52 (2), 77-80.

Chaganti, R., Watts, A. Chaganti, R., \& Zimmerman-Treichel, M. 2008. Ethnicimmigrants in founding teams: Effects on prospector strategy and performance in new Internet ventures. Journal of Business Venturing, 23, 113-139.

Curci, Roberto. (2010). Immigrant business enterprises: A classification framework conceptualization and testThunderbird International Business Review, 52(2), 107121. 
Davidsson, P., Steffens, P., Gordon, S., \& Reynolds, P. (2008). Anatomy of New Business Activity in Australia: Some Early Observations from the CAUSEE Project. (Unpublished).

Evangelista, F. (2005). Qualitative insights into the international new venture creation process. Journal of International Entrepreneurship, 3, 179-198.

Evans, D. \& Leighton, L. (1989). Some empirical aspects of entrepreneurship. The American Economic Review, June.

Fairlie, R. (2008). Estimating the contribution of immigrant business owners to the U.S. economy. Small Business Administration, Office of Advocacy, November 2008, no. 234 .

Fairlie, R., \& Robb, A. (2007). Families, human capital and small business: Evidence from the characteristics of business owners survey. Industrial and Labor Relations Review, 60( 2), 225-245.

Ferrer, A., \& Riddell, W.C. (2008). Education, credentials and immigrant earnings. Canadian Journal of Economics 41, no. 1: 186-216.

Francis, D.H., \& W.R. Sandberg. (2000). Friendship within entrepreneurial teams and its association with team and venture performance. Entrepreneurship Theory and Practice, Winter, 25(2), 5-25.

Georgellis, Y., Sessions, J., \& Tsitsianis, N. (2005a). The effect of windfall gains on selfemployment transitions: UK evidence. Small Business Economics, 25(5), 407428. 
Georgellis, Y., Sessions, J., \& Tsitsianis, N. (2005b). Self-employment longitudinal dynamics: A review of the literature. Economic Issues, 10(2), 51-84.

Granovetter, M.S. (1985). Economic action and social structure: The problem of embeddedness. American Journal of Sociology, 91, 481-510.

Greve, A., \& Salaff, J.W. (2003). Social networks and entrepreneurship. Entrepreneurship Theory and Practice, 28, 1-22.

Hamilton, L.C. (1998). Statistics with STATA 5. Pacific Grove, CA: Brooks/Cole Publishing Company.

Hart, D. and Acs, Z. (2011). High-Tech Immigrant Entrepreneurship in the United States. Economic Development Quarterly. 25(2), 116-129.

Hofstede, G. (1980). Culture's consequences: International differences in work-related values. Beverly Hills, CA: Sage.

Honig, B., \& Drori. I. (2010). A review of related streams of immigration and global entrepreneurship research. In Transnational and Immigrant Entrepreneurship in A Globalized World, eds. B. Honig, I. Drori and B. Carmichael, 199-210. Toronto: University of Toronto Press.

Kariv, D., Menzies, T. V., Brenner, G. A. \& Filion, L. J. (2010). Business success among visible and non-visible ethnic entrepreneurs: a look at the effects of unemployment, co-ethnic involvement and human capital. Global Business and Economics Review, $12(1 / 2), 115-150$ 
Knight, G.A., \& Cavusgil, S.T. (1996). The born global firm: A challenge to traditional internationalization theory. In Advances in International Marketing 8, eds. S.T. Cavusgil and T. Madsen, 11-16. Greenwich, CT: JAI Press.

Lechner, C., Dowling, M. \& Welpe, I. (2006). Firm networks and firm development: The role of the relational mix. Journal of Business Venturing, 21, 514-540.

Light, I. (2010). Forward. In Transnational and Immigrant Entrepreneurship in a Globalized World, eds. B. Honig, I. Drori and B. Carmichael, ix-xv. Toronto: University of Toronto Press.

Luo, Y. (2001). Antecedents and consequences of personal attachment in cross-cultural cooperative ventures. Administrative Science Quarterly, 46, 177-201.

Madsen, T.K., \& Servais, P. (1997). The internationalization of born globals: An evolutionary process. International Business Review, 6, 561-583.

Mata, R., \& Pendakur, R. (1999). Immigration, labor force integration, and the pursuit of self-employment. International Migration Review, 33(2), 378-402.

McDougall, P., Oviatt, B. \& Shrader, R. (2003). A comparison of international and domestic new ventures. Journal of International Entrepreneurship, 1, 59-82.

Mora, M.T., \& Davila, A. (2005). Ethnic group size, linguistic isolation, and immigrant entrepreneurship in the USA. Entrepreneurship and Regional Development, 17, 389-404.

Neri, F., \& Ville, S. (2008). Social capital renewal and the academic performance of international students in Australia. The Journal of Socio-Economics 37, 15151538. 
Ostgaard, T., \& Birley, S. (1996). New venture growth and personal networks. Journal of Business Research, 36(1), 37-50.

Oviatt, B., \& McDougall, P. (1994). Toward a theory of international new ventures. Journal of International Business Studies, 25(1), 45-64.

Paré, S., Menzies, T. V., Filion, L.J. and Brenner, G. (2008). Social capital and coleadership in ethnic enterprises in Canada, Journal of Enterprising Communities: People and Places in the Global Economy, 2(1), 52-72.

Portes, A., Guarnizo, L., \& Haller, W. (2002). Transnational entrepreneurs: An alternative form of immigrant economic adaptation. American Sociological Review, 67(2), 278-298.

Saxenian, A. (2002). Brain circulation: How high-skill immigration makes everyone better off. The Brooking Review, 20, 28-31.

Schlosser, F., \& Kerr, G. (2010). Understanding the pull of transnational entrepreneurship. Presented at Academy of Management Annual Meeting, Montreal, August 2010.

Tsui-Auch, L.S. (2005). Unpacking regional ethnicity and the strength of ties in shaping ethnic entrepreneurship. Organisation Studies 26(8), 1189-1216.

van Tubergen, F. (2005). Self-employment of immigrants: A cross-national study of 17 Western societies. Social Forces, 84 (2), 709-732.

Vernez, G., \& Abrahamse, A. (1996). How immigrants fare in U.S. education. RAND, Santa Monica, CA. Center for Research on Immigration Policy. Sponsored by Andrew W. Mellon Foundation, New York, NY. ISBN-0-8330-2399-3. 
Zhou, M. (2004). Revisiting ethnic entrepreneurship: Convergencies, controversies, and conceptual advancements. International Migration Review, 38(3), 1040-107. 
Table 1 Descriptive variables Young firms $(\mathrm{N}=561)$

\begin{tabular}{|l|l|l|l|l|l|}
\hline Variable & Obs & Mean & Std. Dev. & Min & Max \\
\hline IE & 561 & .2566845 & .4371936 & 0 & 1 \\
\hline INV & 561 & .2067736 & .4053532 & 0 & 1 \\
\hline Team & 561 & .4634581 & .4991079 & 0 & 1 \\
\hline Owners & 561 & .4527629 & 1.104373 & 0 & 6 \\
\hline Uni Ed & 561 & .3761141 & .4848415 & 0 & 1 \\
\hline Depth intl exp & 561 & 4.454545 & 9.75129 & 0 & 51 \\
\hline Breadth int exp & 561 & 1.074866 & 3.993042 & 0 & 50 \\
\hline Bus.owned & 561 & .3832442 & .9825282 & 0 & 12 \\
\hline Ind. Exp. & 561 & 13.32799 & 15.28536 & 0 & 98 \\
\hline Intl Con F2F & 561 & .2442068 & .4299993 & 0 & 1 \\
\hline Intl Con Tech & 561 & .3672014 & .4824723 & 0 & 1 \\
\hline R\&D & 561 & .2495544 & .4331413 & 0 & 1 \\
\hline Hi tech & 561 & .2655971 & .4420448 & 0 & 1 \\
\hline Prop. Tech. & 561 & .0980392 & .2976331 & 0 & 1 \\
\hline
\end{tabular}


Table 2 Correlations Young Firms $(\mathrm{N}=561)$

\begin{tabular}{|c|c|c|c|c|c|c|c|c|c|c|c|c|c|}
\hline & 1. & 2. & 3. & 4. & 5. & 6. & 7. & 8. & 9. & 10. & 11. & 12. & 13. \\
\hline \multicolumn{14}{|l|}{ 1. IE } \\
\hline 2. INV & $.14 * * *$ & & & & & & & & & & & & \\
\hline 3. Team & $-.08+$ & .03 & & & & & & & & & & & \\
\hline 4. Owners & .07 & $.10^{*}$ & $.44 * * *$ & & & & & & & & & & \\
\hline 5. Uni Ed & $.12 * *$ & $.15 * * *$ & .05 & $.17 * * *$ & & & & & & & & & \\
\hline 6. Depth intl & $.42 * * *$ & $.21 * * *$ & $.15 * * *$ & $.36 * * *$ & $.25 * * *$ & & & & & & & & \\
\hline 7. Breadth intl & $.13 * * *$ & $.23 * * *$ & .03 & $.17 * * *$ & $.19 * * *$ & $.43 * * *$ & & & & & & & \\
\hline 8. Bus.owned & .07 & $.12 * * *$ & $.23 * * *$ & $.42 * * *$ & .02 & $.22 * * *$ & $.21 * * *$ & & & & & & \\
\hline 9. Ind. Exp. & $.08+$ & .02 & $.24 * * *$ & $.34 * * *$ & $.14 * * *$ & $.24 * * *$ & .06 & $.18 * * *$ & & & & & \\
\hline 10. Intl Con F2F & $.10 * *$ & $.25 * * *$ & -.02 & $.08+$ & $15^{* * *}$ & $.12 * *$ & $.14 * * *$ & $.09 *$ & .02 & & & & \\
\hline 11. Intl Con Tech & $.17 * * *$ & $.35 * * *$ & -.03 & $.10^{*}$ & $.17 * * *$ & $.25 * * *$ & $.18 * * *$ & $.08+$ & .01 & $.56 * * *$ & & & \\
\hline 12. R\&D & $.09 *$ & $.16^{* * *}$ & .06 & .00 & .06 & .07 & $.12 * *$ & .04 & -.01 & $.13 * * *$ & $.21 * * *$ & & \\
\hline 13. Hi tech & $.10 *$ & $.17 * * *$ & .03 & $.10^{*}$ & $.17 * * *$ & .07 & .02 & .01 & $.07+$ & $-10^{*}$ & $.16^{* * *}$ & $.24 * * *$ & \\
\hline 14. Prop. Tech. & $.14 * * *$ & $.16^{* * * *}$ & .05 & $.15^{* * * *}$ & $.09 *$ & $.16^{* * * *}$ & $.12 * *$ & $.13 * * *$ & $.10^{*}$ & $-11 * *$ & $.12 * * *$ & $.21 * * *$ & $.20 * * *$ \\
\hline
\end{tabular}


Table 3 Logistic regressions of IE on dependent variables in Young Firms ( $\mathrm{N}=516)$

\begin{tabular}{|l|r|r|l|l|r|}
\hline Dependent variable & Odds Ratio & Std. Err & $\mathrm{z}$ & $\mathrm{P}>\mathrm{z}$ & Prob>chi2 \\
\hline INV & 2.10 & .46 & 3.35 & 0.001 & .001 \\
\hline Team & .69 & .13 & -1.88 & 0.060 & .058 \\
\hline Uni Ed & 1.71 & .33 & 2.75 & 0.006 & .006 \\
\hline Intl Con F2F & 1.68 & .36 & 2.42 & 0.015 & .017 \\
\hline Intl Con Tech & 1.18 & .35 & 0.57 & 0.570 & .570 \\
\hline R\&D & 1.61 & .34 & 2.24 & 0.025 & .027 \\
\hline Hi tech & 1.63 & .34 & 2.34 & 0.019 & .020 \\
\hline Prop. Tech. & 2.49 & .72 & 3.13 & 0.002 & .002 \\
\hline
\end{tabular}

$* * * \mathrm{p}<.001, * * \mathrm{p}<.01, * \mathrm{p}<.05,+\mathrm{p}<.10$ 
Table 4 ANOVA tests for differences between IE and NE in $\mathrm{YF}(\mathrm{N}=561)$

\begin{tabular}{|l|c|l|l|l|l|}
\hline Dependent variable & IE Mean & NE Mean & F & Prob>F & Bartlett's \\
\hline Owners & .58 & .41 & 2.72 & .0999 & .001 \\
\hline Depth Intl & 16.64 & 3.61 & 29.41 & .000 & .000 \\
\hline Breadth Intl & 3.27 & 2.58 & .19 & .662 & .427 \\
\hline Bus. Owned & .50 & .34 & 2.74 & .0982 & .467 \\
\hline Ind Exp & 15.43 & 12.60 & 3.68 & .055 & .000 \\
\hline
\end{tabular}


Table 5 Logistic regressions on INV in Young Firms $(\mathrm{N}=516)$

\begin{tabular}{lllll}
\hline Independent variable & Odds Ratio & Std. Err & $\mathrm{Z}$ & $\mathrm{P}>\mathrm{Z}$ \\
\hline Team & 1.00 & 0.27 & 0.01 & 1.00 \\
Num owners & 0.98 & 0.13 & -0.19 & 0.85 \\
Uni ed & 1.21 & 0.30 & 0.77 & 0.44 \\
Depth intl exp & 1.01 & 0.01 & 0.72 & 0.47 \\
Breadth intl exp & 1.15 & 0.08 & 2.03 & 0.04 \\
Num bus own & 1.14 & 0.14 & 1.08 & 0.28 \\
Industry exp & 0.99 & 0.01 & -1.00 & 0.32 \\
Intl Con F2F & 1.40 & 0.39 & 1.21 & 0.23 \\
Intl Con Tech & 3.51 & 0.99 & 4.45 & 0.00 \\
R \& D & 1.25 & 0.34 & 0.83 & 0.41 \\
Hi tech & 1.83 & 0.47 & 2.33 & 0.02 \\
Prop. tech & 1.62 & 0.58 & 1.34 & 0.18 \\
\hline Prob > chi2 & 0.00 & & & \\
Pseudo R2 & 0.19 & & & \\
LR chi2(13) & 106.03 & & & \\
\hline
\end{tabular}

$* * * \mathrm{p}<.001, * * \mathrm{p}<.01, * \mathrm{p}<.05,+\mathrm{p}<.10$ 
Figure 1 Theoretical model of the role of IE in INV

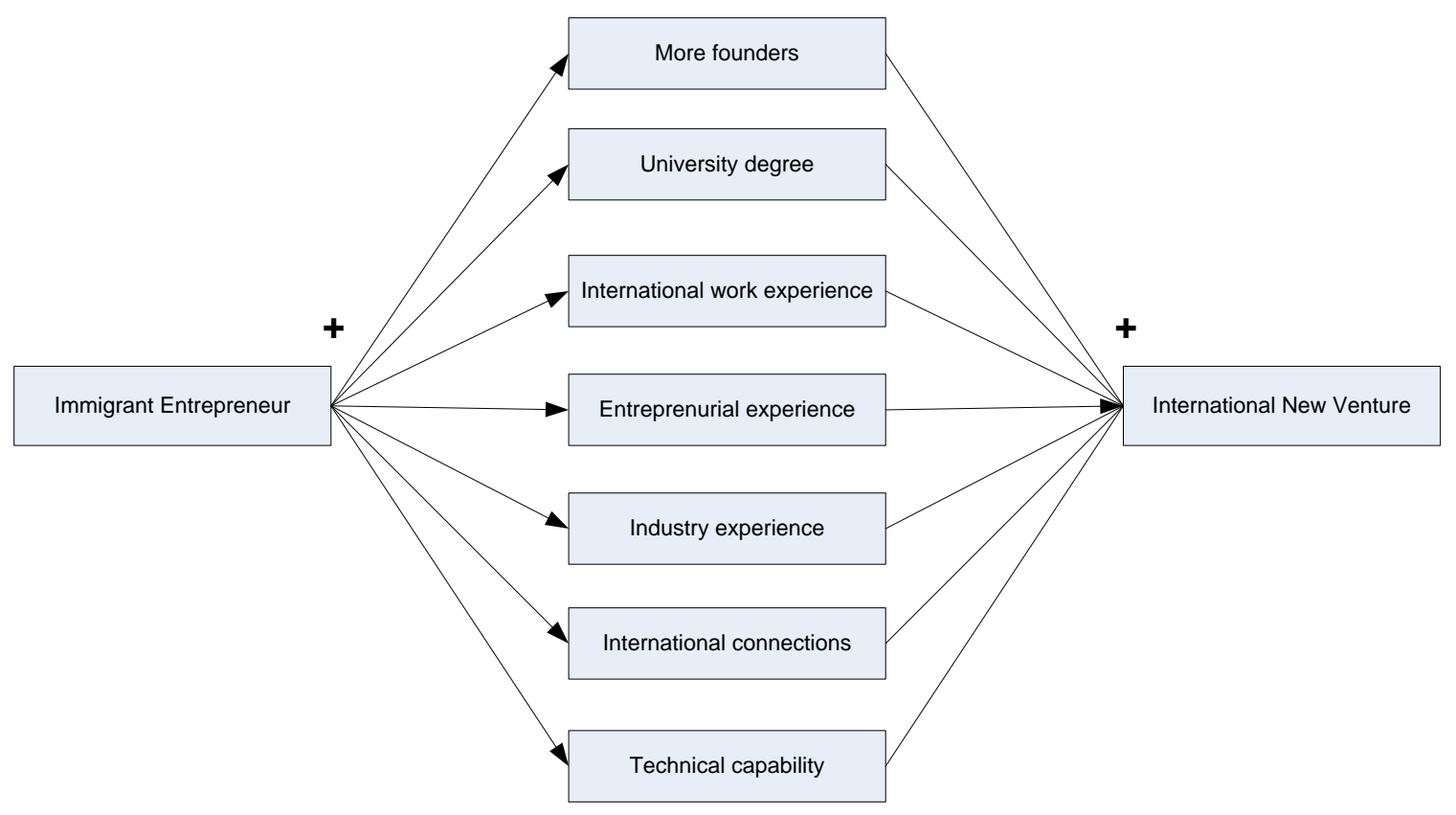


Figure 2 Findings

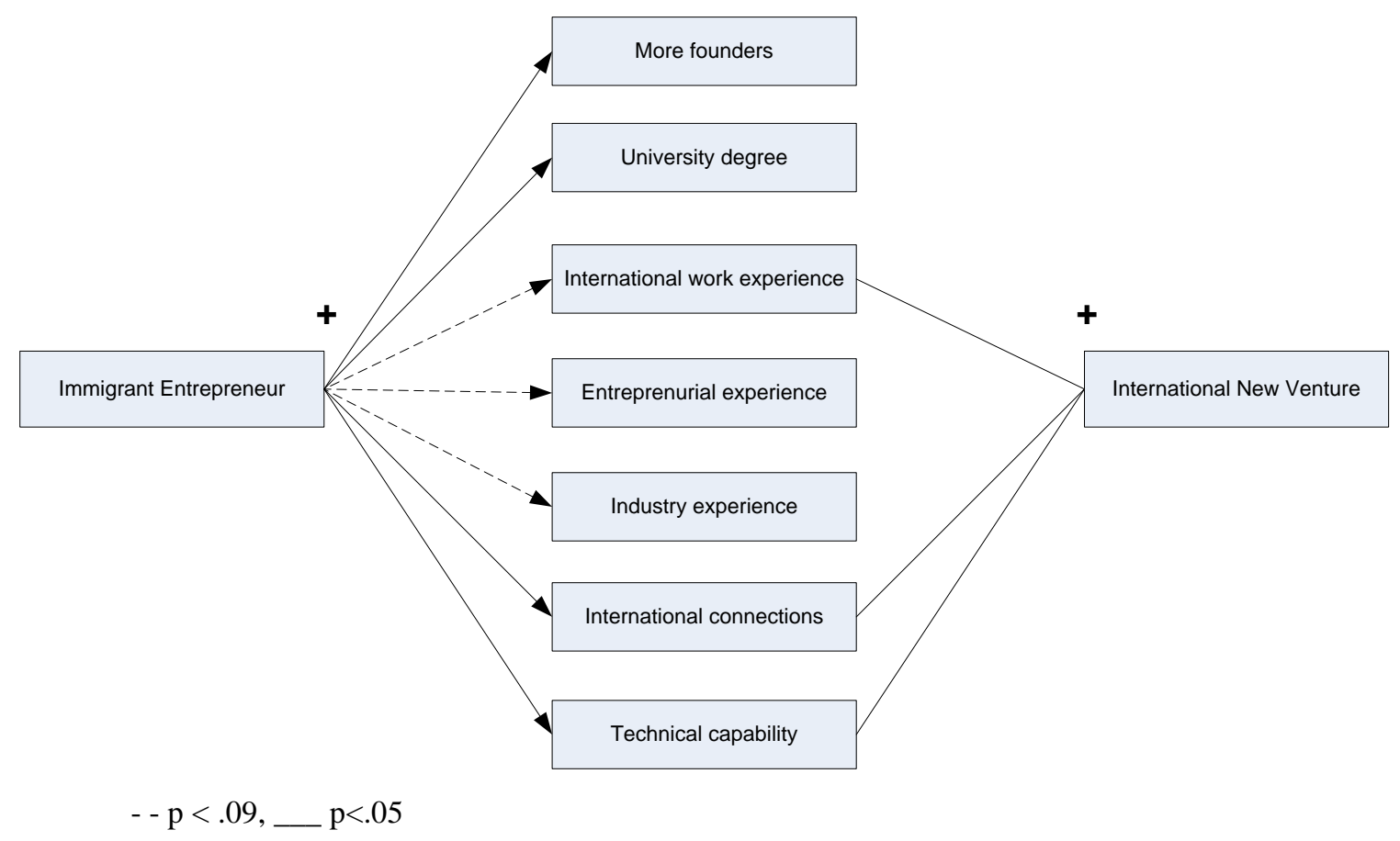

